\title{
PENGARUH BANGKITAN DAN TARIKAN OPERASIONAL UNIT RAWAT JALAN RSU PURI RAHARJA TERHADAP KINERJA LALU LINTAS
}

\author{
Ni Made Widya PRATIWI ${ }^{1 *}$ \\ ${ }^{1}$ Program Studi Teknik Sipil, Fakultas Teknik dan Perencanaan, Universitas Warmadewa, Denpasar, \\ Indonesia \\ *Email korespondensi: deee.widya@gmail.com
}

[diterima: 6 November 2020, disetujui: 4 Januari 2021]

\begin{abstract}
Outpatient Unit of Puri Raharja Hospital is one of the health services provided by Puri Raharja Hospital. The outpatient unit at Puri Raharja Hospital is located at W.R. Supratman street, where the road is a collector road which has a fairly dense road performance. The operation of it, it certainly has an influence on traffic performance in the vicinity. Therefore, it is necessary to study the effect of the Outpatient Unit at Puri Raharja Hospital on traffic performance. This study uses the result data from the traffic survey which is used as the process of calculating traffic performance based on the Indonesian Road Capacity Manual 1997, as well as the vehicle entry and exit survey for the calculation of generation and attraction. From the analysis, it was found that W.R. Supratman street is the busiest movement on weekdays at 17.00 - 18.00 WITA with a traffic volume of $2598.2 \mathrm{pcu} /$ hour. The traffic volume for Gadung street on weekdays, peak hours occur at 12.15-13.15 WITA with a traffic volume of 445.0 pcu/hour. W.R. Supratman street during the peak hours of the working day has a V/C ratio of 0.83 . The number of generated and pulled is $54.4 \mathrm{pcu} / \mathrm{hour}$. The existing condition is the current condition where the Outpatient Unit of Puri Raharja Hospital has been operating. Operation of the Puri Raharja Hospital Outpatient Unit, it had an impact of $2.09 \%$ on traffic performance on W.R. Supratman street in existing conditions.
\end{abstract}

Key words: Trip Production, trip attraction, traffic performance

\section{INTISARI}

Unit Rawat Jalan RSU Puri Raharja merupakan salah satu pelayanan kesehatan yang disediakan oleh RSU Puri Raharja. Unit Rawat Jalan RSU Puri Raharja berlokasi di Jalan W.R. Supratman, dimana jalan tersebut merupakan jalan kolektor yang memiliki kinerja ruas jalan yang cukup padat. Dengan adanya operasional dari Unit Rawat Jalan RSU Puri Raharja ini tentunya memberikan pengaruh terhadap kinerja lalu lintas di sekitarnya. Oleh sebab itu, maka perlu dilakukan kajian mengenai pengaruh Unit Rawat Jalan RSU Puri Raharja terhadap kinerja lalu lintas di sekitarnya. Kajian ini menggunakan data hasil dari survey lalu lintas yang digunakan sebagai proses perhitungan kinerja lalu lintas berdasarkan MKJI 1997, serta survey keluar masuk kendaraan untuk perhitungan bangkitan dan tarikan pusat kegiatan. Dari hasil analisis didapatkan bahwa Jalan W.R. Supratman pergerakan terpadat pada hari kerja terjadi pada pukul 17.00 - 18.00 WITA dengan volume lalu lintas sebesar 2598,2 smp/jam. Volume lalu lintas Jalan Gadung pada hari kerja, jam puncak terjadi pada pukul 12.15 - 13.15 WITA dengan volume lalu lintas sebesar 445,0 smp/jam. Kinerja Jalan W.R. Supratman yang berada di depan lokasi Unit Rawat Jalan RSU Puri Raharja yang terkena dampak langsung dari operasional tersebut. Jalan W.R. Supratman pada jam puncak saat hari kerja memiliki V/C ratio sebesar 0,83. Jumlah bangkitan dan tarikan yang ditimbulkan sebesar 54,4 smp/jam. Kondisi eksisting merupakan kondisi saat ini dimana Unit Rawat Jalan RSU Puri Raharja telah beroperasi. Dengan adanya operasional Unit Rawat Jalan RSU Puri Raharja tersebut berdampak sebesar 2,09\% terhadap kinerja lalu lintas di Jalan W.R. Supratman pada kondisi eksisting.

Kata kunci: Bangkitan, tarikan, kinerja lalu lintas. 


\section{PENDAHULUAN}

Transportasi merupakan usaha memindahkan, mengerakkan, mengangkut, atau mengalihkan suatu objek dari suatu tempat ke tempat lain, dimana di tempat lain ini objek tersebut lebih bermanfaat atau dapat berguna untuk tujuan-tujuan tertentu (Miro, 2005). Semakin banyak kendaraan yang digunakan sebagai sarana perpindahan, maka prasarana yang dibutuhkan juga harus lebih memadai.

Salah satu permasalahan di perkotaan yang sering terjadi akibat transportasi, yaitu penurunan kinerja ruas jalan akibat pembangunan suatu pusat kegiatan. Kinerja ruas jalan merupakan kemampuan ruas jalan untuk melayani arus lalu lintas sesuai dengan fungsinya yang dapat diukur dan dibandingkan dengan standar tingkat pelayanan jalan, dengan nilai tingkat pelayanan jalan dijadikan sebagai parameter kinerja ruas jalan (Suwardi, 2010). Pembangunan suatu pusat kegiatan tentunya mengakibatkan semakin meningkatnya pergerakan yang terjadi.

Pembangunan Unit Rawat Jalan RSU Puri Raharja merupakan unit rawat jalan yang diprakarsai oleh RSU Puri Raharja untuk memberikan pelayanan terbaik bagi masyarakat, sesuai dengan komitmen dari Pemerintah Provinsi Bali.

Unit Rawat Jalan RSU Puri Raharja dibangun dengan luas lahan $1.050 \mathrm{~m}^{2}$, luas lantai bangunan $1.385 \mathrm{~m}^{2}$, dengan 20 ruang praktek. Unit Rawat Jalan RSU Puri Raharja berlokasi di Jalan W.R. Supratman, Denpasar. Berdasarkan hasil analisis yang telah dilakukan, diketahui Jalan W.R Supratman pergerakan terpadat pada hari kerja terjadi pada pukul 17.00 - 18.00 WITA dengan volume lalu lintas sebesar 2598,2 smp/jam, dengan nilai V/C Ratio sebesar 0,83 sehingga tingkat pelayanan ruas jalan termasuk kategori "D". Kecepatan kendaraan pada hari kerja yaitu 23,65 km/jam (Pratiwi, 2018). Dengan adanya kegiatan dari Unit Rawat Jalan RSU Puri Raharja, tentunya akan menambah beban kinerja ruas jalan di sekitarnya, terutama ruas Jalan W.R. Supratman yang sudah memiliki V/C Ratio 0,83. Oleh sebab itu maka dilakukan kajian untuk mengetahui seberapa besar pengaruh operasional dari Unit Rawat Jalan RSU Puri Raharja terhadap kinerja lalu lintas di sekitarnya.

Pada penelitian yang telah dilakukan menggunakan metode klasifikasi silang didapatkan besaran bangkitan rumah sakit di Kota Semarang, dimana besaran bangkitan rumah sakit tipe A (RS Dr. Kariadi) sebesar $110,96 \mathrm{kend} / \mathrm{jam} / \mathrm{ha}$ atau $1,15 \mathrm{kend} / \mathrm{jam} / \mathrm{bed}$ atau 0,31 kend/jam/pegawai, untuk rumah sakit tipe B (RS Elizabeth) sebesar 98,91 $\mathrm{kend} / \mathrm{jam} / \mathrm{ha}$ atau $0,78 \mathrm{kend} / \mathrm{jam} / \mathrm{bed}$ atau 0,45 kend/jam/pegawai, serta untuk rumah sakit tipe C (RS. Sultan Agung) sebesar 229,65 $\mathrm{kend} / \mathrm{jam} / \mathrm{ha}$ atau $1,50 \mathrm{kend} / \mathrm{jam} / \mathrm{bed}$ atau 0,58 kend/jam/pegawai (Kartarajasa, 2007).

Untuk perhitungan bangkitan perjalanan, dengan menggunakan metode Trip Rate Analysis yaitu ditentukan dengan kegiatan pembanding sejenis dengan membandingkan jumlah kendaraan keluar-masuk terhadap luas bangunan yang ada (Muchlisin, 2017).

\section{METODOLOGI PENELITIAN}

Unit Rawat Jalan RSU Puri Raharja merupakan salah satu pelayanan kesehatan yang diberikan oleh RSU Puri Raharja dalam meningkatkan kualitas pelayanan kesehatan. Unit Rawat Jalan RSU Puri Raharja berlokasi di Jalan W.R. Supratman No. 19, Denpasar. Dalam beroperasinya Unit Rawat jalan RSU Puri Raharja ini tentunya menimbulkan dampak terhadap lalu lintas di sekitar lokasi pusat kegiatan. Lokasi Unit Rawat Jalan RSU Puri Raharja ditunjukkan pada Gambar 1. 


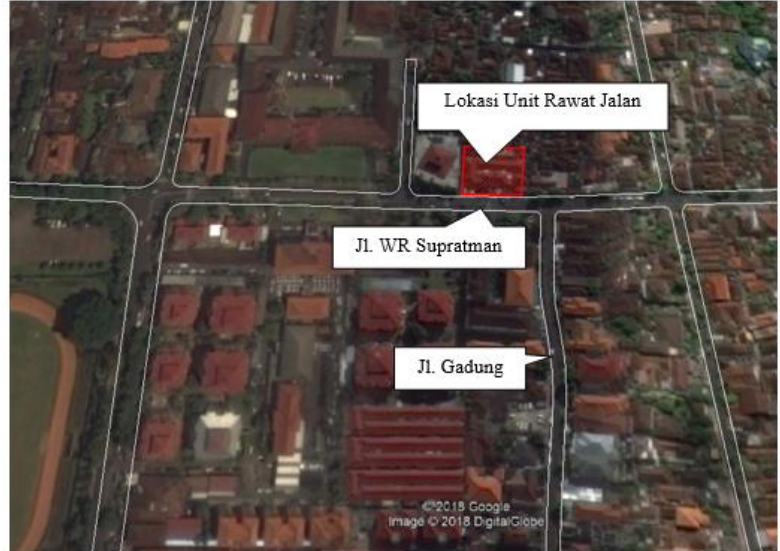

Sumber: (Google.com, 2020)

Gambar 1. Lokasi Unit Rawat Jalan RSU Puri Raharja

Dengan adanya operasional Unit Rawat Jalan RSU Puri Raharja tentunya akan berdampak terhadap ruas jalan yang berada di sekitar lokasi pusat kegiatan. Berikut ini merupakan ruas jalan yang diperkirakan terkena dampak berupa penurunan kinerja ruas jalan akibat adanya operasional tersebut, yang digunakan sebagai wilayah kajian.

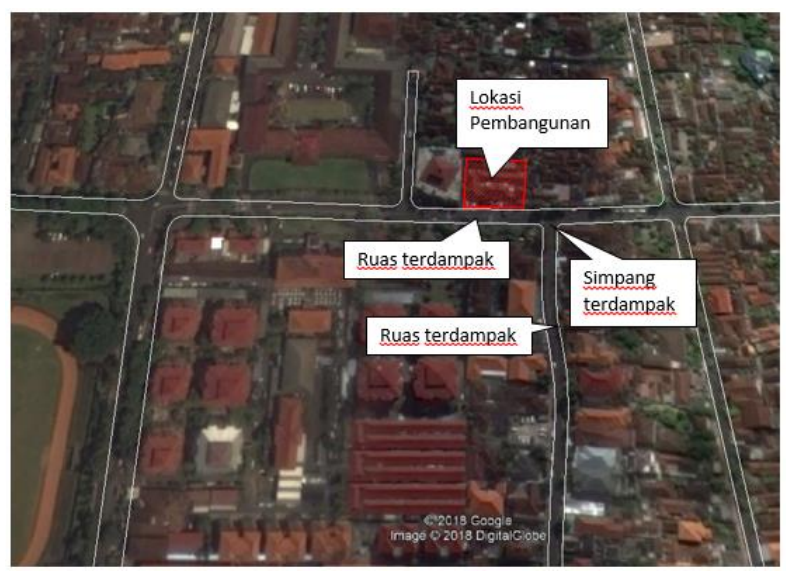

Gambar 2. Lokasi ruas terdampak

Ruas jalan yang diperkirakan terkena dampak akibat adanya pembangunan Unit Rawat Jalan RSU Puri Raharja adalah Jalan WR. Supratman dan Jalan Gadung. Sedangkan simpang yang diperkirakan terdampak adalah Simpang Jl. W.R. Supratman - Jl. Gadung. Metodologi yang digunakan pengambilan data dijabarkan sebagai berikut.

1. Survei pencacahan lalu lintas terklasifikasi: Jalan WR. Supratman dan Jalan Gadung;

2. Survei keluar masuk kendaraan: pada lokasi Unit Rawat Jalan RSU Puri Raharja;
3. Survei Pencacahan Lalu Lintas Terklasifikasi di Simpang Jl. WR. Supratman - Jl. Gadung.

Perhitungan kinerja ruas jalan dilakukan saat kondisi eksisting, yaitu tahun 2018 dan tahun rencana jangka pendek ( 5 tahun), yaitu tahun 2023. Hal ini dilakukan untuk memberikan gambaran kepada stakeholder mengenai kinerja ruas jalan pada jalan kolektor, pada kasus ini ruas Jalan W.R. Supratman, sehinga bisa dipersiapkan kebijakan yang bisa diambil untuk menanggulangi penurunan kinerja ruas jalan seiring dengan pertumbuhan lalu lintas yang terjadi setiap tahun.

Penilaian kinerja ruas jalan tercantum dalam Peraturan Menteri Perhubungan No: KM 14 Tahun 2006, dimana nisbah volume/kapasitas (V/C ratio) adalah perbandingan antara volume lalu lintas dengan kapasitas jalan. Hasil perbandingan tersebut yang digunakan dalam penggolongan tingkat pelayanan jalan (Level of Service) (Menteri Perhubungan, 2006). Tingkat Pelayanan (LoS) merupakan ukuran kualitatif yang mencerminkan persepsi para pengemudi dan penumpang mengenai karakteristik kondisi operasional dalam arus lalu lintas (Transportation Research Board, 1994). Tingkat pelayanan disimbolan dengan huruf A hingga $\mathrm{F}$, dimana Los A menunjukkan kondisi terbaik, dan $\operatorname{LoS} \mathrm{F}$ menunjukkan kondisi terburuk.

Tabel 1. Hubungan V/C Ratio dengan LoS

\begin{tabular}{|c|c|c|c|}
\hline LOS & $\begin{array}{c}\text { KECEPATAN } \\
\text { RATA-RATA } \\
\text { (KM/JAM) }\end{array}$ & $\mathrm{V} / \mathrm{C}$ & DESKRIPSI ARUS \\
\hline A & $\geq 50$ & $\begin{array}{l}\leq \\
0,40\end{array}$ & $\begin{array}{l}\text { Arus bebas bergerak, } \\
\text { pengemudi bebas } \\
\text { memilih kecepatan } \\
\text { sesuai batas yang } \\
\text { ditentukan }\end{array}$ \\
\hline B & $\geq 40$ & $\leq$ & $\begin{array}{l}\text { Arus stabil, kecepatan } \\
\text { operasi mulai dibatasi, } \\
\text { mulai ada hambatan } \\
\text { dari kendaraan lain }\end{array}$ \\
\hline $\mathrm{C}$ & $\geq 32$ & $\begin{array}{c}\leq \\
0,80\end{array}$ & $\begin{array}{l}\text { Arus stabil, kecepatan } \\
\text { terbatas, hambatan } \\
\text { dari kendaraan lain } \\
\text { makin besar }\end{array}$ \\
\hline $\mathrm{D}$ & $\geq 27$ & $\begin{array}{c}\leq \\
0,90\end{array}$ & $\begin{array}{lr}\text { Arus } & \text { mulai tidak } \\
\text { stabil, } & \text { kecepatan }\end{array}$ \\
\hline
\end{tabular}




\begin{tabular}{|c|c|c|c|}
\hline LOS & $\begin{array}{c}\text { KECEPATAN } \\
\text { RATA-RATA } \\
\text { (KM/JAM) } \\
\end{array}$ & v/C & DESKRIPSI ARUS \\
\hline & & & $\begin{array}{l}\text { operasi menurun } \\
\text { relatif cepat akibat } \\
\text { hambatan yang timbul }\end{array}$ \\
\hline $\mathrm{E}$ & $\geq 24$ & $\begin{array}{l}\leq \\
1,00\end{array}$ & $\begin{array}{l}\text { Arus yang tidak } \\
\text { stabil, kadang macet }\end{array}$ \\
\hline $\mathrm{F}$ & $<24$ & $\begin{array}{c}> \\
1,00\end{array}$ & $\begin{array}{l}\text { Macet, antrian } \\
\text { panjang }\end{array}$ \\
\hline
\end{tabular}

Untuk analisis data dalam penentuan trip rate, digunakan pengembangan sebagai dasar penentuan persamaan dalam menentukan trip rate (Tamin, 2000), yaitu:

$\frac{X}{T R}=\frac{X^{\prime}}{100 m^{2}}$

Dimana:

\section{TR : Nilai Trip Rate}

X : Jumlah kendaraan yang keluar/masuk (smp/jam) pada lokasi pembanding

$X^{\prime}$ : Luas bangunan pada lokasi pembanding (smp/jam)

\section{HASIL DAN PEMBAHASAN}

\section{Volume Lalu Lintas}

\section{Jalan W.R. Supratman}

Berdasarkan hasil survey, didapatkan hasil inventarisasi Jalan W.R. Supratman dengan lebar badan jalan $10 \mathrm{~m}$, jumlah lajur 2, lebar lajur $5 \mathrm{~m}$, lebar bahu jalan kiri maupun kanan masing-masing $0,5 \mathrm{~m}$, dengan lebar trotoar 1,5 m, kondisi jalan baik, dan dengan status jalan merupakan jalan provinsi.

Data volume lalu lintas di ruas jalan di peroleh dari hasil survey pencacahan lalu lintas di ruas jalan (traffic counting). Survey traffic counting dilaksanakan selama 2 hari, yaitu 1 hari kerja dan 1 hari libur. Survey dilaksanakan dari pukul 06.00 - 22.00 WITA. Data yang dipakai untuk analisa adalah data volume lalu lintas pada saat jam sibuk. Berdasarkan hasil survey tersebut, diperoleh data sebagai berikut.

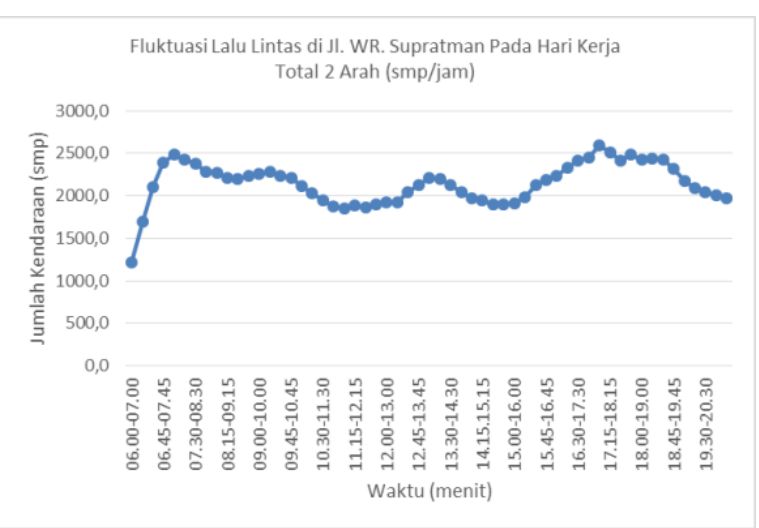

Gambar 3. Fluktuasi lalu lintas Jalan W.R. Supratman pada hari kerja

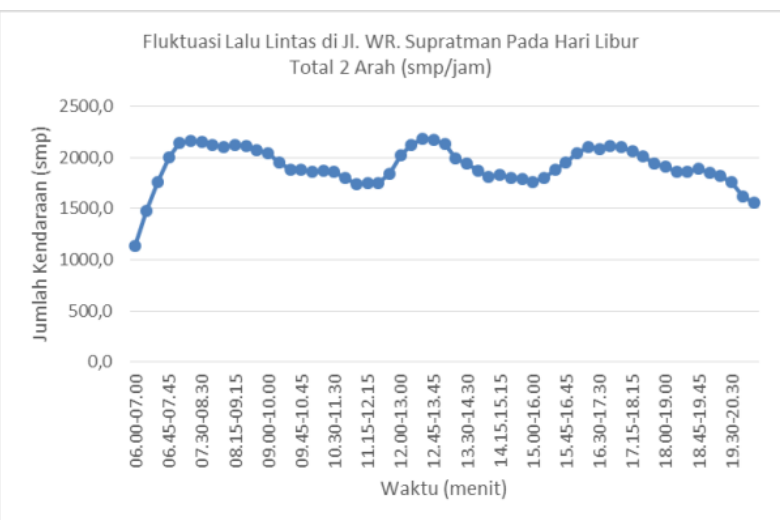

Gambar 4. Fluktuasi lalu lintas Jalan W.R. Supratman pada hari libur

Berdasarkan hasil pengamatan di lapangan, volume kendaraan di kedua arah lalu lintas pada Jalan WR. Supratman baik pada saat hari kerja maupun hari libur tidak terlalu jauh berbeda. Pergerakan terpadat pada hari kerja terjadi pada pukul $17.00-18.00$ WITA dengan volume lalu lintas sebesar 2598,2 smp/jam. Sedangkan jam terpadat pada hari libur terjadi pada pukul 12.30 - 13.30 WITA dengan volume lalu lintas sebesar 2180,6 smp/jam.

\section{Jalan Gadung}

Berdasarkan hasil survey, didapatkan hasil inventarisasi Jalan Gadung dengan lebar badan jalan $6 \mathrm{~m}$, jumlah lajur 2, lebar lajur 3 $\mathrm{m}$, dengan lebar trotoar $1,2 \mathrm{~m}$, kondisi jalan baik, tipe jalan 2/1 UD, dan dengan status jalan merupakan jalan kota.

Data volume lalu lintas di ruas jalan di peroleh dari hasil survey pencacahan lalu lintas di ruas jalan (traffic counting). Survey traffic counting dilaksanakan selama 2 hari, yaitu 1 hari kerja dan 1 hari libur. Survey 
dilaksanakan dari pukul 06.00 - 22.00 WITA. Data yang dipakai untuk analisa adalah data volume lalu lintas pada saat jam sibuk. Berdasarkan hasil survey tersebut, diperoleh data sebagai berikut.

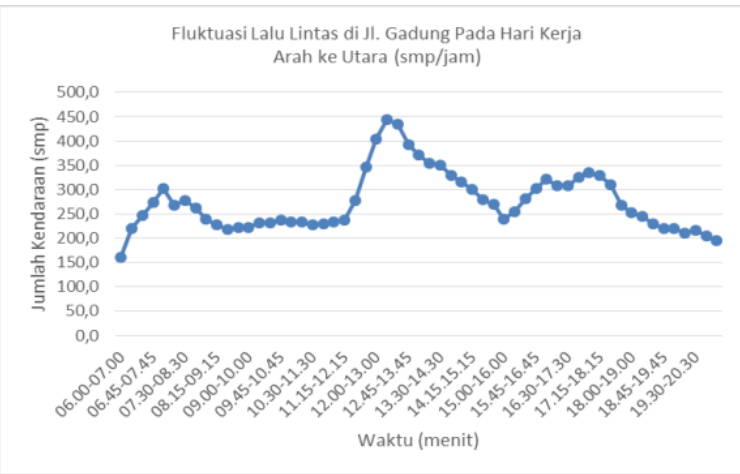

Gambar 5. Fluktuasi lalu lintas Jalan Gadung pada hari kerja

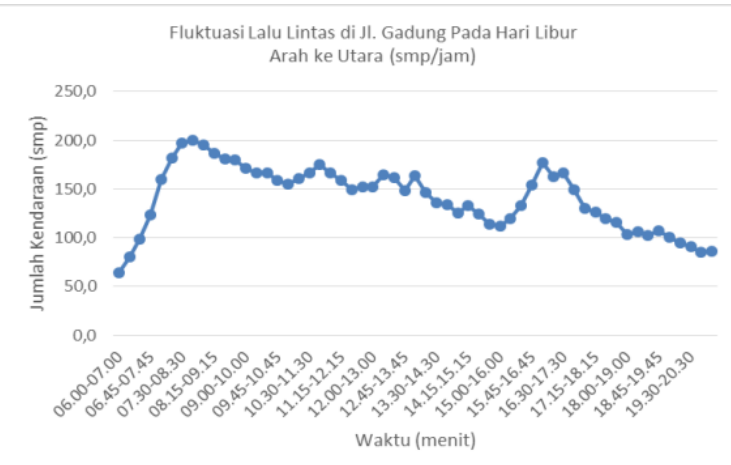

Gambar 6. Fluktuasi lalu lintas Jalan Gadung pada hari libur

Volume lalu lintas Jalan Gadung pada hari kerja maupun hari libur terjadi perbedaan yang signifikan. Pada hari kerja, jam puncak di Jalan Gadung terjadi pada pukul 12.15 13.15 WITA dengan volume lalu lintas sebesar 445,0 smp/jam. Sedangkan pada hari libur, jam puncak terjadi pada pukul 07.45 08.45 WITA dengan volume lalu lintas sebesar 200,5 smp/jam.

\section{V/C Ratio}

Dari hasil survey pencacahan lalu lintas terklasifikasi dan analisis yang dilakukan oleh konsultan, dapat diketahui nilai $\mathrm{V} / \mathrm{C}$ ratio pada ruas jalan di depan lokasi yang terkena dampak akibat adanya Operasional Unit Rawat Jalan RSU Puri Raharja sebagai berikut.
Tabel 2. V/C Ratio ruas jalan pada hari kerja

\begin{tabular}{cccc}
\hline RUAS JALAN & $\begin{array}{c}\text { VOLUME } \\
\text { (SMP/JAM) }\end{array}$ & $\begin{array}{c}\text { KAPASITAS } \\
\text { (SMP/JAM) }\end{array}$ & $\begin{array}{c}\text { V/C } \\
\text { RATIO }\end{array}$ \\
\hline $\begin{array}{c}\text { W.R. } \\
\text { Supratman } \\
\text { Gadung }\end{array}$ & 2598,2 & 3129,72 & 0,83 \\
\hline
\end{tabular}

Tabel 3. V/C Ratio ruas jalan pada libur

\begin{tabular}{cccc}
\hline RUAS JALAN & $\begin{array}{c}\text { VOLUME } \\
\text { (SMP/JAM) }\end{array}$ & $\begin{array}{c}\text { KAPASITAS } \\
\text { (SMP/JAM) }\end{array}$ & $\begin{array}{c}\text { V/C } \\
\text { RATIO }\end{array}$ \\
\hline $\begin{array}{c}\text { W.R. } \\
\text { Supratman } \\
\text { Gadung }\end{array}$ & 2180,6 & 3129.72 & 0.70 \\
\hline
\end{tabular}

Berdasarkan tabel di atas, dapat diketahui kinerja Jalan W.R. Supratman yang berada di depan lokasi Unit Rawat Jalan RSU Puri Raharja yang terkena dampak langsung dari operasional tersebut. Jalan W.R. Supratman pada jam puncak saat hari kerja memiliki V/C ratio sebesar 0,83 atau mempunyai Level of Service (LOS) dengan kategori "D". Sementara untuk jam puncak saat hari libur, Jalan WR. Supratman memiliki V/C ratio sebesar 0,70 atau mempunyai Level of Service (LOS) dengan kategori "C".

Sedangkan kinerja Jalan Gadung yang berada di sekitar lokasi dan terkena dampak akibat adanya pembangunan Unit Rawat Jalan RSU Puri Raharja pada jam puncak saat hari kerja memiliki V/C ratio sebesar 0,18 atau mempunyai Level of Service (LOS) dengan kategori "A". Sementara untuk jam puncak saat hari libur, Jalan Gadung memiliki V/C ratio sebesar 0,08 atau mempunyai Level of Service (LOS) dengan kategori "A".

\section{Kecepatan}

Kecepatan merupakan indikator lalu lintas yang dapat memperkuat penentuan penilaian kinerja lalu lintas. Pada ruas-ruas jalan yang dilakukan survey traffic counting juga dilakukan survei kecepatan titik (spot speed) yang bertujuan untuk mengetahui kecepatan rata-rata kendaraan di ruas jalan tersebut. Survey ini dilakukan pada penggal ruas Jalan WR. Supratman dan Jalan Gadung yang berada di sekitar lokasi Unit Rawat Jalan RSU Puri Raharja yang terkena dampak dari pembangunan tersebut, dengan panjang pengamatan 50 meter. 
Survei kecepatan titik (spot speed) dilakukan pada saat jam sibuk pagi, jam tidak sibuk, dan jam sibuk sore. Berikut ini merupakan rata-rata kecepatan titik untuk kedua arah lalu lintas di Jalan WR. Supratman dan Jalan Gadung.

Tabel 4. Kecepatan kendaraan

\begin{tabular}{ccc}
\hline \multirow{2}{*}{ RUAS JALAN } & \multicolumn{2}{c}{ KECEPATAN (KM/JAM) } \\
\cline { 2 - 3 } & HARI KERJA & HARI LIBUR \\
\hline W.R. Supratman & 23,65 & 26,43 \\
Gadung & 34,72 & 37,48 \\
\hline
\end{tabular}

Berdasarkan tabel di atas, kecepatan kendaraan di Jalan W.R. Supratman pada hari kerja yaitu 23,65 km/jam, sedangkan kecepatan pada hari libur yaitu $26,43 \mathrm{~km} / \mathrm{jam}$. Untuk kecepatan kendaraan di Jalan Gadung pada hari kerja yaitu $34,72 \mathrm{~km} / \mathrm{jam}$, sedangkan kecepatan pada hari libur yaitu 37,48 km/jam.

\section{Kinerja Simpang Terdampak}

Simpang Jl. WR Supratman - Jl. Gadung berada di sebelah timur lokasi pembangunan dengan jarak \pm 30 meter dari lokasi pembangunan. Jenis pengendalian simpang tersebut adalah simpang prioritas dimana lalu lintas dari pendekat Jalan Gadung memberikan prioritas terhadap lalu lintas pada pendekat Jalan WR Supratman. Berikut ini merupakan gambar layout Simpang Jl. WR Supratman - Jl. Gadung.

Berdasarkan hasil survey gerakan membelok di persimpangan dan analisa yang dilakukan, diperoleh kinerja Simpang Jl. WR Supratman - Jl. Gadung sebagai berikut.

Tabel 5. Kinerja Simpang Jl. W.R. Supratman - Jl. Gadung

\begin{tabular}{ccc}
\hline $\begin{array}{c}\text { ARUS LALU } \\
\text { LINTAS } \\
\text { SMP/JAM }\end{array}$ & $\begin{array}{c}\text { KAPASITAS } \\
\text { SMP/JAM }\end{array}$ & $\begin{array}{c}\text { DERAJAT } \\
\text { KEJENUHAN }\end{array}$ \\
\hline 1042,06 & 2894,62 & 0,36 \\
\hline
\end{tabular}

Tabel 6. Tundaan Simpang Jl. W.R. Supratman Jl. Gadung

\begin{tabular}{ccl}
\hline TUNDAAN LL & TUNDAAN & TUNDAAN \\
SIMPANG & GEOMETRIK & SIMPANG \\
DET/SMP & SIMPANG DET/SMP & DET/SMP \\
\hline 9,34 & 11,82 & 21,16 \\
\hline
\end{tabular}

Berdasarkan tabel di atas, diketahui bahwa Simpang Jl. WR Supratman - Jl.
Gadung mempunyai nilai derajat kejenuhan sebesar 0,36 dan tundaan simpang sebesar $21,16 \mathrm{det} / \mathrm{smp}$. Tingkat pelayanan simpang tersebut adalah $\mathrm{C}$ karena memiliki tundaan antara 15 detik sampai dengan 25 detik.

\section{Bangkitan/Tarikan Lalu Lintas}

Besarnya bangkitan dan tarikan perjalanan yang disebabkan oleh operasional Unit Rawat Jalan RSU Puri Raharja didasarkan pada hasil survey kendaraan keluar masuk lokasi tersebut. Survey tersebut dilakukan dengan cara mencatat seluruh kendaraan yang masuk ke lokasi maupun yang keluar dari lokasi. Survey dilaksanakan pada akses keluar masuk lokasi tersebut.

\section{Tarikan Perjalanan}

Berdasarkan hasil survey tersebut, diperoleh data bahwa kendaraan masuk ke Unit Rawat Jalan RSU Puri Raharja terbanyak terjadi pada siang hari, yaitu pukul 11.45 12.45 WITA. Jam tersebut merupakan jam terpadat kendaraan masuk ke lokasi. Tarikan perjalanan yang diakibatkan oleh operasional Unit Rawat Jalan RSU Puri Raharja pada jam padat tersebut sebesar 23,80 smp/jam dengan jumlah kendaraan roda 2 yang masuk ke lokasi sebanyak 37 kendaraan dan roda 4 sebanyak 9 kendaraan.

\section{Bangkitan Perjalanan}

Berdasarkan hasil survey tersebut, diperoleh data bahwa kendaraan yang keluar dari lokasi terbanyak terjadi pada siang hari, yaitu pukul $12.45-13.45$ WITA. Jam padat tersebut merupakan jam terpadat kendaraan keluar dari lokasi. Bangkitan perjalanan dari operasional Unit Rawat Jalan RSU Puri Raharja pada jam padat tersebut sebesar 30,60 smp/jam dengan jumlah kendaraan roda 2 yang keluar dari lokasi sebanyak 49 kendaraan dan roda 4 sebanyak 11 kendaraan.

\section{Hasil Analisis Trip Rate}

Trip Rate Analysis merujuk pada beberapa model yang berdasarkan rata-rata bangkitan perjalanan atau dari tarikan perjalanan yang terkait dengan bangkitan penting pada suatu wilayah (Papacostas \& Prevedouros, 1993). 
Analisis trip rate Unit Rawat Jalan RSU Puri Raharja dihitung dengan membandingkan luasan bangunan yaitu $1.385 \mathrm{~m}^{2}$ per- $100 \mathrm{~m}^{2}$ dengan volume kendaraan keluar masuk. Contoh perhitungan pada jam terpuncak adalah sebagai berikut.

1. Trip Rate Tarikan

$$
\begin{gathered}
\frac{\text { Kend. Masuk }}{\text { Trip Rate }}=\frac{\text { Luas Bangunan }}{100 \mathrm{~m}^{2}} \\
\frac{23,80 \mathrm{smp} / \mathrm{jam}}{\text { Trip Rate }}=\frac{1.385 \mathrm{~m}^{2}}{100 \mathrm{~m}^{2}} \\
\text { Trip Rate Masuk }=1,72 \mathrm{smp} / \mathrm{jam}
\end{gathered}
$$

\section{Trip Rate Bangkitan}

$$
\begin{aligned}
& \frac{\text { Kend. Keluar }}{\text { Trip Rate }}=\frac{\text { Luas Bangunan }}{100 \mathrm{~m}^{2}} \\
& \frac{30,60 \mathrm{smp} / \mathrm{jam}}{\text { Trip Rate }}=\frac{1.385 \mathrm{~m}^{2}}{100 \mathrm{~m}^{2}} \\
& \text { Trip Rate Keluar }=2,21 \mathrm{smp} / \mathrm{jam}
\end{aligned}
$$

Berdasarkan perhitungan di atas, diketahui bahwa Unit Rawat Jalan RSU Puri Raharja memiliki trip rate tarikan sebesar 1,72 smp/jam, sedangkan trip rate bangkitan sebesar 2,21 smp/jam.

Berdasarkan jumlah bangkitan dan tarikan yang ditimbulkan oleh operasional Unit Rawat Jalan RSU Puri Raharja. Jumlah bangkitan dan tarikan yang ditimbulkan sebesar 54,4 smp/jam. Kondisi eksisting merupakan kondisi saat ini dimana Unit Rawat Jalan RSU Puri Raharja telah beroperasi. Dengan adanya operasional Unit Rawat Jalan RSU Puri Raharja tersebut berdampak sebesar 2,09\% terhadap kinerja lalu lintas di Jalan W.R. Supratman pada kondisi eksisting.

\section{Kinerja Lalu Lintas pada Tahun Rencana}

Pada tahun rencana 2023, indikator kinerja lalu lintas yang dianalisis adalah indikator kapasitas ruas jalan yang terkena dampak, indikator v/c ratio ruas jalan yang terkena dampak, dan indikator derajat kejenuhan simpang yang terkena dampak.

\section{Kapasitas Jalan Tahun Rencana}

Pada tahun rencana 2023, menggunakan kondisi tanpa adanya perubahan geometrik jalan pada ruas jalan yang terkena dampak, sehingga diasumsikan bahwa kapasitas jalan pada tahun rencana 2023 sama dengan kapasitas jalan tahun eksisting.

Berikut ini merupakan kapasitas ruas jalan yang terkena dampak akibat pembangunan Unit Rawat Jalan RSU Puri Raharja pada tahun rencana 2023.

Tabel 7. Kapasitas Ruas Jalan pada Tahun 2023

\begin{tabular}{cc} 
NAMA RUAS JALAN & KAPASITAS SMP/JAM \\
\hline W.R. Supratman & 3129,72 \\
Gadung & 2539,92 \\
\hline
\end{tabular}

\section{V/C Ratio Tahun Rencana}

Dalam memprediksi besarnya bangkitan dan tarikan perjalanan pada tahun rencana 2023, menggunakan faktor pertumbuhan kendaraan di Kota Denpasar sebesar 6\% per tahun. Faktor pertumbuhan kendaraan tersebut diperoleh dari data Badan Pusat Statistik (BPS) Kota Denpasar, yaitu dengan membandingkan jumlah kendaraan di Kota Denpasar selama 5 tahun terakhir.

Berikut ini merupakan V/C ratio ruas jalan yang terkena dampak akibat pembangunan Unit Rawat Jalan RSU Puri Raharja pada tahun rencana 2023.

Tabel 8. Kinerja Ruas Jalan pada Tahun 2023

\begin{tabular}{cccc}
\hline RUAS JALAN & $\begin{array}{c}\text { VOLUME } \\
\text { (SMP/JAM) }\end{array}$ & $\begin{array}{c}\text { KAPASITAS } \\
\text { (SMP/JAM) }\end{array}$ & $\begin{array}{c}\text { V/C } \\
\text { RATIO }\end{array}$ \\
\hline $\begin{array}{c}\text { W.R. } \\
\text { Supratman } \\
\text { Gadung }\end{array}$ & 23477,0 & 3129,72 & 1,11 \\
\hline
\end{tabular}

Dari tabel di atas, dapat diketahui terjadi peningkatan volume lalu lintas pada ruas jalan yang terkena dampak pada tahun rencana sehingga mengakibatkan meningkatnya nilai $\mathrm{v} / \mathrm{c}$ ratio ruas jalan tersebut. Peningkatan volume lalu lintas tersebut disebabkan karena faktor pertumbuhan kendaraan di Kota Denpasar sebesar 6\% per tahun. Prediksi V/C ratio ruas jalan tersebut adalah apabila selama 5 tahun kedepan tidak dilakukan peningkatan ruas jalan oleh Pemerintah Daerah sehingga dengan kapasitas ruas jalan yang tetap sementara jumlah kendaraan terus meningkat maka menyebabkan $\mathrm{V} / \mathrm{C}$ ratio ruas jalan tersebut meningkat.

Jalan WR Supratman yang berada di 
depan lokasi pembangunan pada tahun rencana 2023 memiliki nilai $\mathrm{V} / \mathrm{C}$ ratio 1,11 . $\mathrm{V} / \mathrm{C}$ ratio ruas jalan tersebut mengalami peningkatan dibandingkan kondisi eksisting, dimana pada kondisi eksisting ruas jalan tersebut memiliki v/c ratio 0,83 . Jalan WR Supratman memiliki tingkat pelayanan jalan "F", yang menandakan bahwa arus lalu lintas pada ruas jalan tersebut dipaksakan atau macet pada kecepatan yang rendah dengan antrian yang panjang dan terjadi hambatan-hambatan yang besar.

Jalan Gadung yang berada di sekitar lokasi pembangunan dan terkena dampak akibat adanya pembangunan Unit Rawat Jalan RSU Puri Raharja pada tahun rencana 2023 memiliki v/c ratio 0,23 . V/C ratio ruas jalan tersebut juga mengalami peningkatan dibandingkan kondisi eksisting. Pada tahun rencana 2023, Jalan Gadung memiliki tingkat pelayanan jalan "B", yang menandakan bahwa ruas jalan tersebut berada dalam zona arus stabil dan pengemudi memiliki kebebasan yang cukup dalam memilih kecepatan.

\section{Kinerja Simpang Tahun Rencana}

Berdasarkan analisa yang dilakukan, diperoleh kinerja Simpang J1. WR Supratman - Jl. Gadung pada tahun rencana 2023 sebagai berikut.

Tabel 9. Kinerja Simpang Jl. W.R. Supratman - Jl. Gadung

\begin{tabular}{ccc}
\hline $\begin{array}{c}\text { ARUS LALU } \\
\text { LINTAS } \\
\text { SMP/JAM }\end{array}$ & $\begin{array}{c}\text { KAPASITAS } \\
\text { SMP/JAM }\end{array}$ & $\begin{array}{c}\text { DERAJAT } \\
\text { KEJENUHAN }\end{array}$ \\
\hline 1394,51 & 2894,62 & 0,48 \\
\hline
\end{tabular}

Tabel 10. Tundaan Simpang Jl. W.R. Supratman Jl. Gadung

\begin{tabular}{|c|c|c|}
\hline $\begin{array}{l}\text { TUNDAAN LL } \\
\text { SIMPANG } \\
\text { DET/SMP }\end{array}$ & $\begin{array}{c}\text { TUNDAAN } \\
\text { GEOMETRIK } \\
\text { SIMPANG } \\
\text { DET/SMP }\end{array}$ & $\begin{array}{l}\text { TUNDAAN } \\
\text { SIMPANG } \\
\text { DET/SMP }\end{array}$ \\
\hline 12,23 & 14,04 & 26,27 \\
\hline
\end{tabular}

Dari perbandingan unjuk kinerja ruas jalan dan kinerja persimpangan di atas, dapat diketahui bahwa terjadi penurunan kinerja ruas jalan dan kinerja simpang (derajat kejenuhan) untuk masing-masing tahun analisis. Dengan belum adanya penanganan
(Do Nothing) dapat dilihat bahwa kapasitas ruas jalan dan simpang tetap sehingga semakin meningkatnya volume lalu lintas di persimpangan namun tanpa diiringi dengan peningkatan kapasitas simpang dapat mengakibatkan kinerja ruas jalan dan simpang semakin menurun.

\section{KESIMPULAN}

Dari hasil analisis ini didapatkan beberapa kesimpulan sebagai berikut. Ruas Jalan W.R. Supratman pada tahun 2018 memiliki volume lalu lintas sebesar 2598,2 smp/jam yang terjadi pada hari kerja dengan nilai $\mathrm{V} / \mathrm{C}$ ratio sebesar 0,83. Ruas Jalan Gadung pada tahun 2018 memiliki volume lalu lintas sebesar 440 smp/jam dengan nilai V/C ratio sebesar 0,18 . Operasional Unit Rawat Jalan RSU Puri Raharja membangkitkan perjalanan sebesar 30,6 smp/jam dan manarik perjalanan sebesar 23,8 smp/jam, sehingga mempengaruhi sebesar 2,09\% dari kinerja ruas Jalan W.R. Supratman.

\section{REFERENSI}

Google.com. (2020, Oktober 15). Retrieved from

https://www.google.com/maps/place/U nit+Rawat+Jalan+RS.+Puri+Raharja+ Denpasar

Kartarajasa, E. (2007). Karakteristik dan Tingkat Bangkitan Lalu Lintas Rumah Sakit di Semarang (Tesis). Semarang: Universitas Diponegoro.

Menteri Perhubungan. (2006). Peraturan Menteri Perhubungan Nomor: KM 14 Tahun 2006 tentang Manajemen dan Reklayasa Lalu Lintas di Jalan . Jakarta.

Miro, F. (2005). Perencanaan Transportasi untuk Mahasiswa, Perencana, dan Praktisi. Jakarta: Erlangga.

Muchlisin. (2017). Analisis Bangkitan Perjalanan dengan Metode Trip-Rate Analysisi (Studi Kasus: Pengembangan Hotel Sheraton Mustika Yogyakarta). Konferensi Nasional Teknik Sipil 11. Jakarta. 
Papacostas, C., \& Prevedouros, P. (1993).

Transportation Engineering and Planning.

Pratiwi, N. W. (2018). Analisis Kinerja Ruas Jalan dan Fasilitas Pejalan Kaki (Studi Kasus: Jalan W.R. Supratman, Denpasar). Paduraksa, 77 - 87.

Suwardi. (2010). Jurnal Teknik Sipil Vol. 7 No. 2.

Tamin, O. (2000). Perencanaan dan Pemodelan Transportasi. Bandung: ITB.

Transportation Research Board. (1994). Highway Capacity Manual Special Report 209. Washington, D.C. 